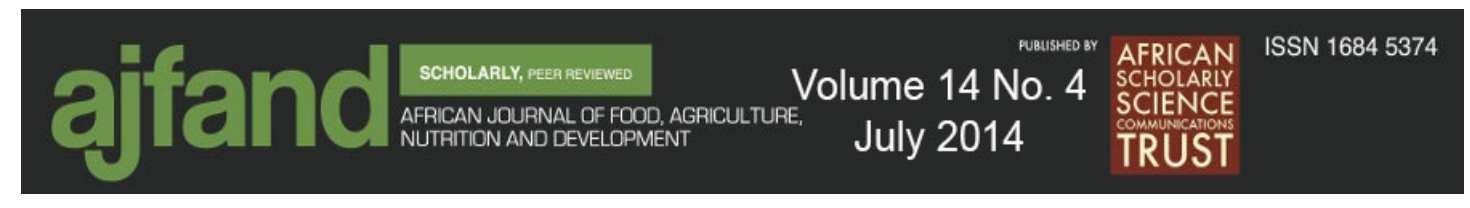

\title{
EVALUATION OF SOIL SOLARISATION AND BIO-FUMIGATION FOR THE MANAGEMENT OF BACTERIAL SPOT OF TOMATO
}

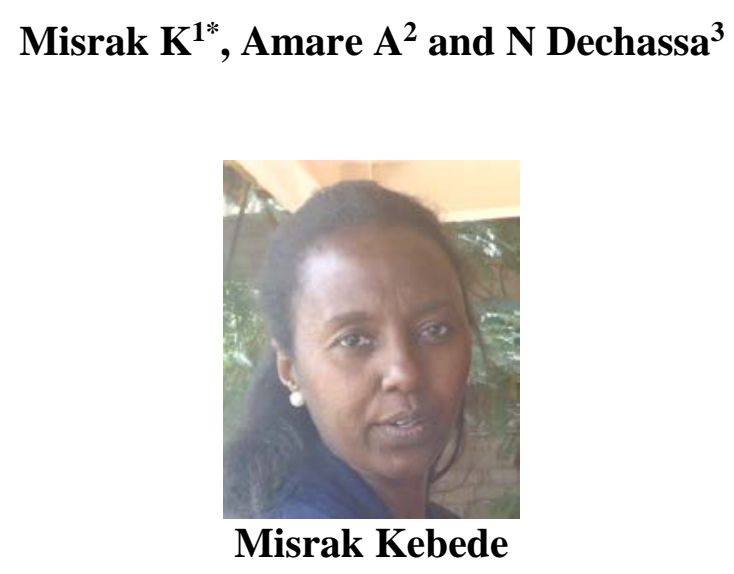

*Corresponding author e-mail: $\underline{\text { msrk_kebede@yahoo.com }}$

${ }^{1}$ MSc, School of Plant Sciences, Haramaya University, P O Box 262, Dire Dawa, Ethiopia

${ }^{2,3} \mathrm{PhD}$, Associate Professor, School of Plant Sciences, Haramaya University, P O Box 138, Dire Dawa, Ethiopia. 


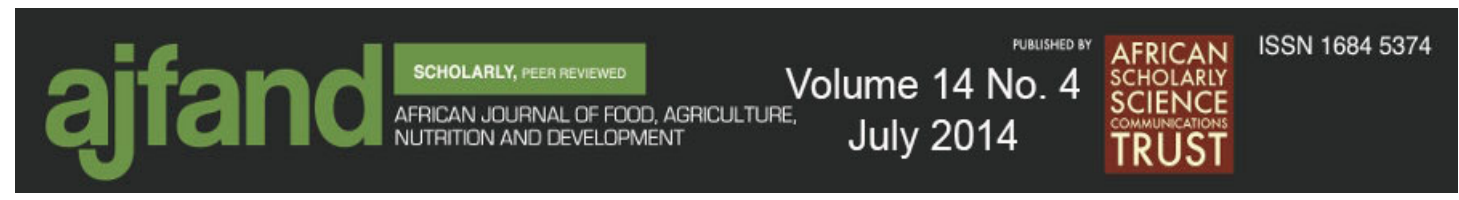

\begin{abstract}
Soil-borne plant pathogens cause heavy losses to all major crops, leading to reductions in both yield and quality. Soil solarisation and bio-fumigation offer disease management options that are safe and reduce the use of pesticides for soil-borne plant pathogens. Mustard plant releases antimicrobial hydrolysis products, notably isothiocyanates when used as a bio-fumigant. Bacterial spot of tomato caused by Xanthomonas campestris pv. vesicatoria (Xcv) can survive in soil and plant debris, which serve as a primary inoculum for infecting the next tomato crop. An experiment was carried out with the objective of evaluating effects of soil solarisation and the use of Ethiopian mustard (Brassica carinata A. Braun) as a bio-fumigant to control bacterial spot disease and on yield of tomato. The treatments consisted of six types of potted soil medium (solarised at Haramaya and Dire Dawa, bio-fumigated, biofumigated as well as solarised at Haramaya and Dire Dawa, and untreated control as non-solarised non-biofumigated pots). Treated tomato seeds were planted and fruit yields were compared among treatments. Potted soil was inoculated with the pathogen, $\mathrm{Xcv}$, belonging to T2P2 race group. The total microbial and $\mathrm{XcV}$ counts were done before as well as after setting up the experiment. The results revealed that solarisation reduced the population of Xcv from 10.68 to $8.79 \mathrm{CFU} \mathrm{g}^{-1}$, total bacterial population from 11.27 to $9.86 \mathrm{CFU} \mathrm{g}^{-1}$, and total actinomycete counts from 11.69 to 9.44 CFU g ${ }^{-1}$ while bio-fumigation had a non-significant effect on Xcv and total microbial counts. None of the treatments exhibited a significant effect on fungal counts. The fruit yield of tomato grown on biofumigated as well as solarised soil was the highest (91.18 t ha-1) as compared to the other treatments. It can, therefore, be concluded that solarisation and bio-fumigation cannot be used as a bio-rational option for effective management of Xcv on tomato but the two methods could be used to increase tomato yield in the presence of the pathogen.
\end{abstract}

Key words: bio-fumigation, solarisation, bacterial leaf spot 


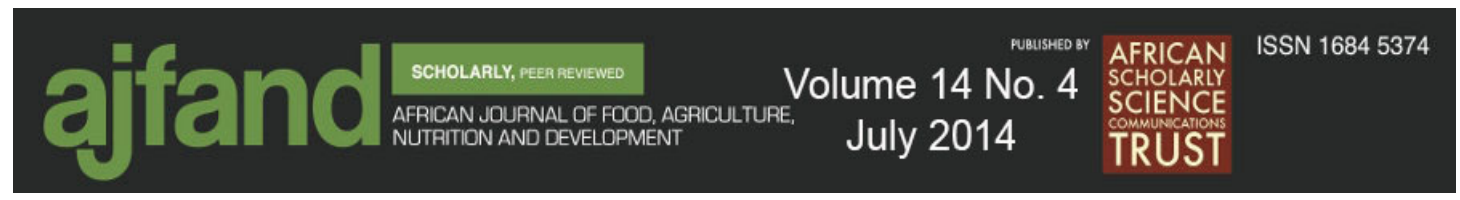

\section{INTRODUCTION}

Soil solarisation (SS) was introduced in 1976 with the aim of managing plant diseases [1]. The main principle of SS is to raise the temperature of a moistened soil. Mulching soil with transparent polyethylene is the most common method of carrying out this practice. Soil-borne species including Agrobacterium spp., Streptomyces scabies, Clavibacter michiganensis Subsp. michiganensis are among bacterial plant pathogens managed by SS [1]. Various studies have shown stimulation of populations of beneficial microorganisms in solarised soils [2, 3]. These include microorganisms such as Trichoderma spp., fluorescent Pseudomonads, Bacillus spp. and Talaromyces spp. which are also potential inducers of disease resistance in plants [4].

The use of plant products as a source of new pesticides is another strategy of managing plant diseases. Plants produce numerous chemicals that can elicit biochemical defence against pathogens. These chemicals may have general or specific activities against key target sites in bacteria, fungi, and viruses. Exploiting the biochemical warfare that occurs between plants and their pathogens is promising in providing new natural products. Bio-pesticides are effective in small quantities and decompose quickly, resulting in lower exposure and fewer pollution problems than conventional pesticides [5].

Members of the Brassicaceae plant family, including mustard, rape, canola, and cabbage are known to produce glucosinolate compounds (GSL). Glucosinolate compounds are a class of sulphur compounds occurring as secondary metabolites almost exclusively in plants belonging to the Order Capparales, which includes the Brassicaceae [5]. They are characterized by a common chemical entity ( $\beta$ thioglucoside with a sulphonated oxime moiety) with a variable chemical side chain that distinguishes individual types [6]. All GSL containing plants also produce a hydrolytic enzyme (thioglucosidase hydrolase) commonly known as myrosinase, which is physically separated from the GSLs in the intact plant tissue [7]. Upon tissue disruption, the myrosinase hydrolyzes the GSLs to form a number of hydrolysis products, a dynamic evolutionary link that has led to the term 'glucosinolatemyrosinase system' [8]. These products have been recognized as broad spectrum biocides [9].

A system involving incorporating mustard green manures to replace conventional metham sodium treatment in potato fields has provided adequate management of pathogens that cause diseases like Verticillium, Sclerotinia, Helminthosporium, and Meloidogyne [10]. An improvement in soil structure and soil protection, maintenance of yield and quality, and a cost saving of around 169 US Dollars per hectare were 


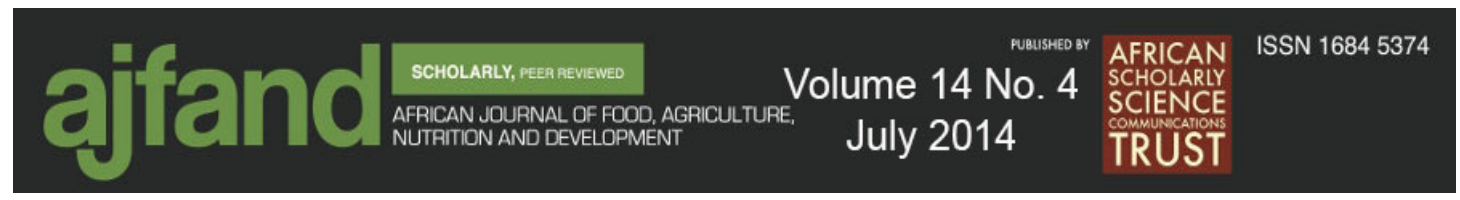

additional advantages over methyl bromide fumigation to disinfect the soil. Moreover, this technique is relevant to smallholder farmers in developing countries who often face the problem of covering costs of using pesticides [10].

The type, concentration, and distribution of GSLs in different plant parts vary between Brassica species and cultivars and so the capacity to generate Isothiocyanates (ITC) varies accordingly. The proportion of total GSLs which were ITC liberating also varied considerably from close to $100 \%$ in the various mustard species (Brassica juncea, B. carinata, B. nigra) to $50 \%$ or less in rapeseed (B. napus) and other Brassica vegetables (B. oleracea). Thus, it is possible to select biofumigants which produce high biomass, with high concentrations of ITC liberating GSLs [11]. The Ethiopian mustard (Brassica carinata A. Braun) is known to have high levels of seed glucosinolates $\left(160 \mu \mathrm{mol} \mathrm{g}^{-1}\right)$ [12].

\section{MATERIALS AND METHODS}

\section{Experimental sites}

The experiment was conducted at Haramaya and Dire Dawa, Ethiopia, during MayJune 2012. Haramaya is located at $42^{\circ} 3^{\prime} \mathrm{E} 9^{\circ} 26^{\prime} \mathrm{N}$ and Dire Dawa is situated at $41^{\circ} 85^{\prime} \mathrm{E} 9^{\circ} 6^{\prime} \mathrm{N}$. Dire Dawa and Haramaya have altitudes of 1176 and 1980 metres above sea level with annual minimum temperature of $17-21^{\circ} \mathrm{C}$ and $8-10^{\circ} \mathrm{C}$ and maximum temperatures of $25-35^{\circ} \mathrm{C}$ and $20-25^{\circ} \mathrm{C}$, respectively [13]. The minimum, maximum and mean temperatures for May, June and July are described in Table 1. All laboratory work was done at Haramaya University's plant pathology laboratory and glasshouse. Solarisation was conducted at the fields of Haramaya University's research sites on the main campus and Dire Dawa.

\section{Treatments and experimental design}

The treatments consisted of six types of potted soil [solarised at Dire Dawa, solarised at Haramaya, bio-fumigated (BF), BF as well as solarised at Dire Dawa, BF as well as solarised at Haramaya, and non-solarised non-BF (control)]. The experiment was laid out in a randomized complete block design (RCBD) with three replications. The treatments were assigned to each pot randomly.

\section{Experimental procedure}

Mustard seeds were planted in pots in a glasshouse at Haramaya. Pots used for all experiments had the capacity of containing $3 \mathrm{~kg}$ of soil. When the mustard plants initiated flowering, the shoot part was chopped up and mixed with potted soil.

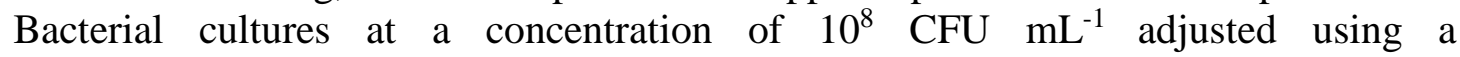
spectrophotometer (0.15 absorbance at $600 \mathrm{~nm}$, Jenway 6400 spectrophotometer) 


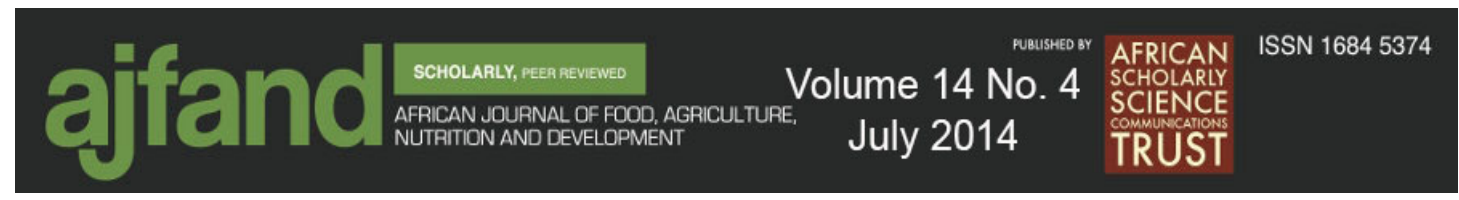

were prepared and inoculated in to the potted soils with and without shreds of mustard shoots. The pots mixed with soil-mustard shoot were left in the glasshouse for 15 days for bio-fumigation to take place. Then, for soil solarisation (SS), pots that were mixed with bacterial samples and half of the BF pots were solarised at Dire Dawa and Haramaya. Soil samples were taken before mixing, after mixing with shredded mustard shoot and after bio-fumigation, before inoculation and after inoculation of bacterial samples, before and after solarisation. Finally, tomato seeds inoculated with bacterial samples and treated with Atella were planted in all experimental units. There were three replications for each experiment and 2 plants in each pot. Cultural practices were done as needed to ensure and maintain good plant growth, including fertilizer application and weeding. Disease incidence and severity were recorded once a week. Incidence was recorded as percentages of plants showing symptoms of the disease while disease severity was recorded on a 1-6 scale, where $1=$ no disease; 2 = $1-3 \%$ infection; $3=5-12 \%$ infection; $4=12-25 \%$ infection; $5=25-50 \%$ infection and 6 $=>50 \%$ infection.

\section{Bacterial inoculum preparation and soil inoculation}

Cultures of $\mathrm{XcV}$ belonging to T2P2 race group were used for inoculation of the experimental pots. The inoculum was prepared by incubating the isolate at $27^{\circ} \mathrm{C}$ for $24 \mathrm{hr}$ on a sucrose peptone agar and suspending the bacteria in sterile distilled water at a concentration of approximately $10^{8} \mathrm{CFU} \mathrm{mL} \mathrm{m}^{-1}$ adjusted using a spectrophotometer [14]. Additionally, $100 \mathrm{~g}$ of tomato plant leaves were shredded and mixed with the soil in each pot because the Xcv cannot survive for a long period without a proper host [15].

\section{Seed inoculation and treatment}

Tomato seeds of the variety 'Marglobe', which is susceptible to Xcv, were inoculated with the pathogenic bacteria by placing $50 \mathrm{~g}$ of seed in $200 \mathrm{ml} \mathrm{Xcv}$ inoculum under a vacuum using a vacuum pump (FJC 6909 3.0 CFM Auto AC Vacuum Pump). The seeds were soaked for 30 minutes and the vacuum was broken abruptly to favour penetration of the bacteria into the seed cavities. Seeds were placed in sterile Petri dishes and allowed to dry for 3 hours in a laminar flow hood [16].

Tomato seeds were treated with Atella (residue of a local beer) based on its efficacy against Xcv without affecting seed viability [17]. Atella was collected from a nearby village that had prepared the traditional drink, 'tella'. The 'Atella' was filtered through a piece of cheese cloth. The filtrate was filter sterilized using $0.45 \mu \mathrm{m}$ Millipore type HAWP. The inoculated tomato seeds were dipped into the Atella filtrate for 3 hours. The treated seeds were allowed to dry in a laminar flow hood for 3 hours. 


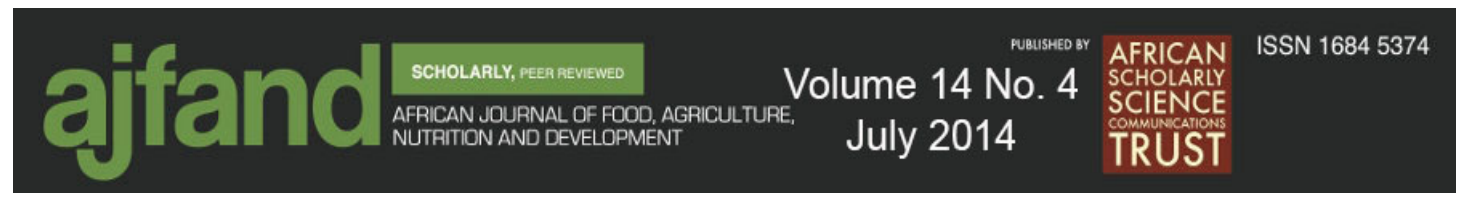

\section{Bio-fumigation}

Seeds of Ethiopian mustard were obtained from Holetta Agricultural Research Centre. The seeds were planted in pots in a glasshouse at the experimental site of Haramaya University. Before flowering (30 days after emergence), the shoot of the plant was chopped. Two hundred gram of the chopped shoot was incorporated into each pot containing $3 \mathrm{~kg}$ soil [18]. The soil was then moistened with water to increase the rate of decomposition. The incorporated shoots were left to decompose in the pots for 15 days at room temperature in the glasshouse [11].

\section{Soil solarisation}

All pots were moistened before the soil solarisation (SS) treatment. Pots were covered with a transparent polyethylene sheet of $15 \mathrm{~mm}$ thickness for four weeks. Soil temperature was recorded daily for the solarised treatments at 5 and $15 \mathrm{~cm}$ depths every 4 hours from 06 am to 06 pm using a thermometer (Brannan, UK). Solarisation was done at Dire Dawa and Haramaya University's campus. Non-solarised pots were maintained on the lab tables at room temperature $\left(10-18^{\circ} \mathrm{C}\right)$. Additionally, Xcvinoculated pots were both BF and solarised.

\section{Soil microbial count}

Soil samples were taken from each experimental pot before and at the end of SS and bio-fumigation. Composite samples were taken to determine total microbial population, including fungi, bacteria and actinomycetes, using serial dilution methods [19]. Soil samples in each pot were mixed well and $10 \mathrm{~g}$ subsamples were taken. Then $100 \mathrm{ml}$ sterilized distilled water was added into each soil sample, shaken for 20 minutes using a shaker (Stuart scientific flask shaker), allowed to settle and diluted with sterilized water. At the proper dilution for colony counting, $0.1 \mathrm{ml}$ of the soil suspension was aseptically transferred into the various media in Petri dishes, spread with an L-shaped glass rod and incubated at $28^{\circ} \mathrm{C}$. The media used in this experiment were Sabouraud Agar, Chitin Agar, and Tryptic Soy Agar to determine the population of fungi, actinomycetes and bacteria, respectively. Colonies of bacteria, fungi and actinomycetes that appeared on the plates were counted 48 hours, 72 hours, and 9 days after incubation, respectively.

Additionally, the population of Xcv was estimated by taking soil samples before inoculation, after inoculation, and at the end of SS and bio-fumigation. Bacterial population was isolated from other microorganisms in the soil using Tryptic soy agar. Then, selective medium, SX agar and Tween media were used to isolate Xcv colonies with typical Xcv morphology [20]. The colonies were counted and the CFU g ${ }^{-1}$ for each plate was calculated. 


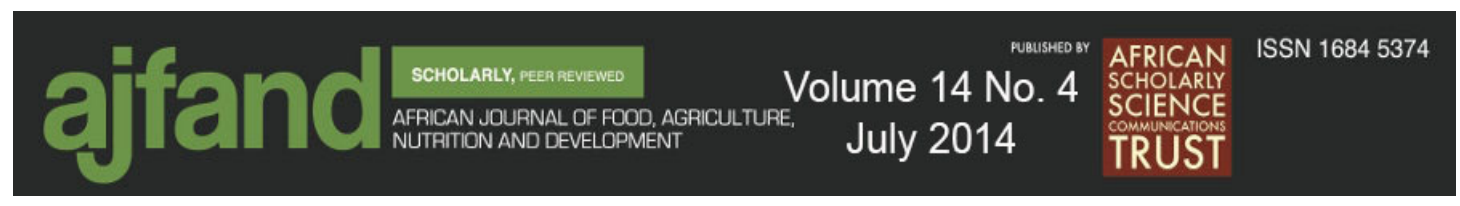

\section{Determination of tomato yield}

Tomato fruits were harvested at maturity several times, as determined by colour break, and weighed successively for four weeks. The yield was converted to tonne per hectare and the effect of SS and bio-fumigation was estimated.

\section{Statistical analysis}

Total microbial and Xcv counts were subjected to analysis of variance (ANOVA) using the SAS software (SAS Institute, version 9.1, Cary, NC) and means were separated using the least significant difference (LSD) test at 5\% level of significance.

\section{RESULTS}

\section{Bio-fumigation}

The populations of bacteria, fungi, and actinomycetes in soils among mustard plant mixed inoculated soil, mixed un-inouculated soil, inoculated soil, and un-inouculated soil were not significantly different. Following soil bio-fumigation for two weeks, the populations of the bacteria, actinomycestes, and fungi remained the same (Table 2). The population of Xcv in the mustard-treated and inoculated soil was $10.57 \mathrm{CFU} \mathrm{g}^{-1}$ while after bio-fumigation it significantly decreased to $8.79 \mathrm{CFU} \mathrm{g}{ }^{-1}$. Tomato planted on the inoculated BF soil did not develop Xcv disease symptoms. Tomato yield obtained from the BF soil amounted to $45.78 \mathrm{t} \mathrm{ha}^{-1}$, which was significantly higher than the yield obtained from the solarised soil by $43 \%$ and the non-BF soils by $49 \%$ (Table 3).

Soil samples from the $\mathrm{BF}$ and solarised pots possessed statistically comparable number of bacterial population (11.63 CFU g$~^{-1}$ ), actinomycetes (10.71 CFU g${ }^{-1}$ ) and fungi (9.32 CFU g ${ }^{-1}$ ) which were statistically similar to the non-solarised non-BF, inoculated soil, mustard mixed inoculated soil and BF soil (Table 2). The population of Xcv was $8.79 \mathrm{CFU} \mathrm{g}^{-1}$ for BF and solarised soil which was in statistical parity with the population of $\mathrm{Xcv}$ recorded in both BF and solarised soil $\left(8.84 \mathrm{CFU} \mathrm{g} \mathrm{g}^{-1}\right.$ ). Tomato seeds planted on both BF and solarised soils did not exhibit disease symptoms due to infection by Xcv in the soil. The highest yield of the crop was recorded for BF as well as solarised soil at Dire Dawa $\left(91.18 \mathrm{t} \mathrm{ha}^{-1}\right)$ which was higher than the yield obtained from non-solarised non-BF soil by $60.46 \mathrm{t} \mathrm{ha}^{-1}$ (197\%) (Table 3).

\section{Soil Solarisation}

During SS, the highest and lowest temperatures recorded were $55^{\circ} \mathrm{C}$ and $10^{\circ} \mathrm{C}$ at Haramaya and $60^{\circ}$ and $20^{\circ} \mathrm{C}$ at Dire Dawa (Table 4). The results revealed that uninoculated soil before SS harboured $10.73 \mathrm{CFU} \mathrm{g}{ }^{-1}$ bacteria, $11.05 \mathrm{CFUg}^{-1}$ 


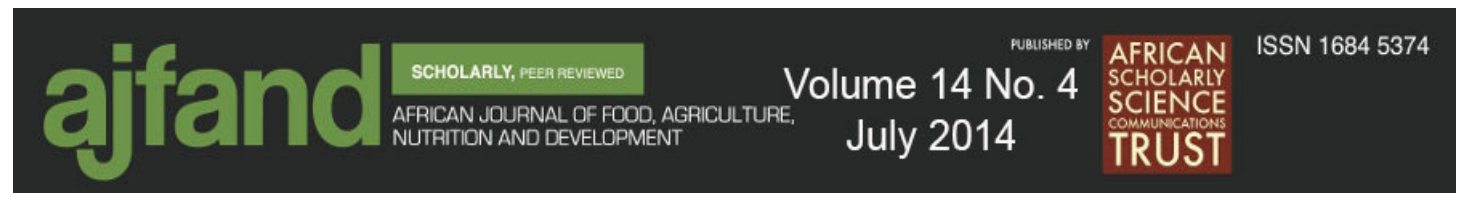

actinomycetes and 9.5 CFU g-1 fungi per gram of soil (Table 2). After inoculation with Xcv and before SS, the population of bacteria, actinomycetes and fungi did not change significantly. However, after SS for one month, the population decreased significantly from 11.27 to $9.86 \mathrm{CFU} \mathrm{g}^{-1}$ for bacteria and from 11.69 to $9.44 \mathrm{CFUg}^{-1}$ for actinomycetes. On the other hand, the fungi population remained statistically the same (changed from 10.67 to $9.72 \mathrm{CFU} \mathrm{g}^{-1}$ ).

The population of Xcv in the un-inoculated soil was zero while after inoculation it increased significantly to $10.68 \mathrm{CFU} \mathrm{g}^{-1}$ per gram of soil. Solarisation significantly altered the population of Xcv from 10.68 to $8.79 \mathrm{CFU} \mathrm{g}^{-1}$. The non-solarised non-BF soil after a month at room temperature had a significantly changed population of XcV from 10.68 to $8.62 \mathrm{CFU} \mathrm{g}^{-1}$. The tomato seeds planted on the solarised soil did not show the disease symptom of Xcv. The tomato yield for solarised soils were $31.94 \mathrm{t}$ $\mathrm{ha}^{-1}$ and $35.85 \mathrm{t} \mathrm{ha}^{-1}$ for Haramaya and Dire Dawa, respectively (Table 3). Comparing the yield of solarised soil with that of un-solarised as well as BF soil there were an 85\% and 154\% increase in the yield at Haramaya and Dire Dawa, respectively.

\section{DISCUSSION}

The study showed that soil bio-fumigation and soil solarisation (SS) reduced the population of Xcv but complete elimination of the pathogen was not attained. Likewise the populations of soil bacteria and actinomycetes decreased after the treatments. On the other hand, BF as well as solarised soil and soil which was only BF significantly increased tomato fruit yield in the presence of Xcv as compared to the non-solarised non-BF soil. Soil solarisation is a non-chemical scheme that improves the tilth and nutrient status of soil. It has already been reported that micro-organisms beneficial to plant growth were stimulated (Rhizobium spp. and Trichoderma spp.) or were less affected (Bacillus spp. and Actinomycetes) by SS as compared to pathogenic organisms [2; 3]. Temperatures associated with soil steaming usually exceed the maximum temperatures $\left(60^{\circ} \mathrm{C}\right.$ to $\left.61.5^{\circ} \mathrm{C}\right)$ that can be tolerated by eukaryotic organisms and some non-spore forming bacteria [21]. Opara and Odibo [22] showed that the growth of Xcv was affected as the temperature increased above $40^{\circ} \mathrm{C}$. These results corroborate the findings of the present study which revealed that solarisation of the soil significantly reduced the population of Xcv. The highest temperatures recorded in response to SS were $60^{\circ} \mathrm{C}$ at Dire Dawa and $55^{\circ} \mathrm{C}$ at Haramaya which could have caused the reduction in the total bacterial count and the Xcv population. Moreover, SS reduced the population of actinomycetes but had no significant effect on the population of fungi in the soil. It was also reported that reductions of actinomycetes occurred during SS [23]. However, this result is inconsistent with that of Stapleton and DeVay [2] who reported a lesser effect of 


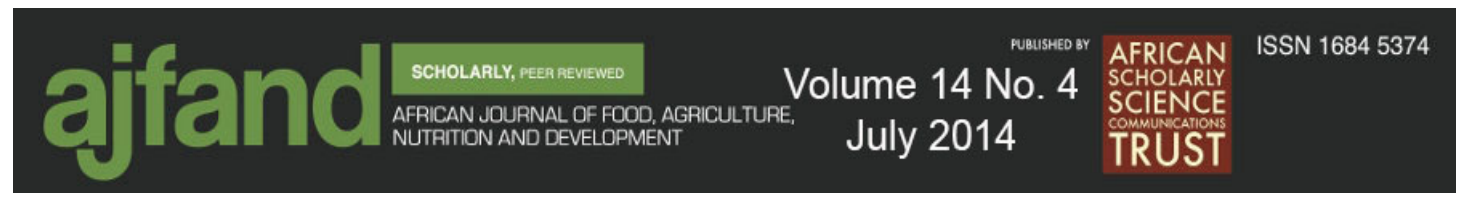

solarisation on population of actinomycetes. These differences could be attributed to the variations in magnitude of temperature, light intensity, soil texture, soil moisture, and soil depth, which also play important roles in the survival of microorganisms during SS [24].

The presence of Xcv in the soil had no significance on the yield of tomato due to SS and bio-fumigation. Consistent with this suggestion, a study showed that during solarisation of soil, positive changes occur in the structure of soil, in solubility of mineral substances available for plant and microbial growth, and in the populations of soil-borne microorganisms [25]. These changes affect the inoculum density of plant pathogens, and also their aggressiveness and survival. Changes in the populations of other soil-borne microorganisms occur during and after SS which may influence disease suppression of the soil and enhance plant growth. This selective action of SS is consistent with the findings from the present study which showed the reduction of $\mathrm{Xcv}$, bacteria and actinomycetes population.

Mustard BF soil had significant effect on the population of Xcv, but not on total bacterial, fungal and actinomycetes counts as compared to mustard-mixed inoculated soil. A similar study on the effect of mustard extract on the Xcv inoculated tomato seeds showed that it had effect on the Xcv population after $24 \mathrm{~h}$ of soaking [17]. Similarly, in a soil amended with mustard seed meal, it was shown that there were insignificant differences among microbial communities in amended soil compared to the unamended soil after 28 day of bio-fumigation [26]. However, there was a significant effect on specific microbes like nitrifying bacteria which increased in soil amended with mustard seed meal. The population of fungi also increased more in the amended treatments than in that unamended treatments which substantiates the results of this study. In the present study, it was initially assumed that mustard bio-fumigation would broadly inhibit the growth of soil bacterial and fungal populations. However, it did not affect the population of these organisms. This could be attributed to the fact that mustard inhibited some microbes in the soil and at the same time it may have stimulated growth and proliferation of other microbes since bio-fumigation may have increased the soil organic carbon content, which is the energy source for the microbial processes [27]. In the contrary, adverse effects of mustard on various soil microbes especially fungi have been documented $[10,28]$. Therefore, further research on the effect of mustard during bio-fumigation on various soil types, on different soil microbes in diverse environmental conditions is needed to verify the present work. Although, mustard bio-fumigation reduced the effect on soil microbes, tomato yield increased in mustard BF soil compared to non-BF soil. It was shown that plots with incorporated Indian mustard into the soil produced more marketable fruit yield than plots with the control treatment [29]. 


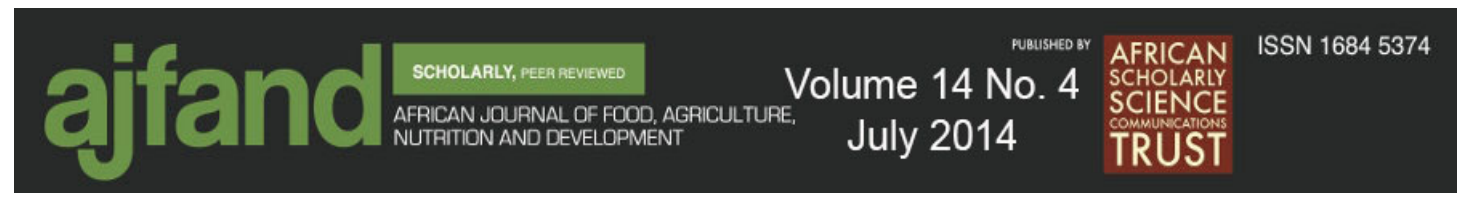

Bio-fumigated solarised soil reduced the population of Xcv but not the total microbial counts of bacteria, fungi and actinomycetes as compared to mustard-mixed inoculated soil. The total bacterial and actinomycetes counts recorded from the BF solarised soils were higher than those from the BF soil. This could be due to the additional plant material (mustard) which could be the source of nutrients and carbon for growth and proliferation of the microbes in the soil. Similarly, it was shown that a higher number of bacteria were found in solarised and soils amended with neem cake powder than in solarised soil without neem cake powder [30]. The yield of tomato obtained from BF solarised soil was higher as compared to solarised soil alone. Similarly, the yield of tomato obtained from BF soil was lower than that obtained from BF solarised soil for the reason that SS and bio-fumigation increased the fertility of the soil, thereby promoting more growth and productivity of the crop [25]. Similarly, it was reported that SS increased nitrogen, calcium, and magnesium availability in addition to extractable phosphate and potassium [3]. The increased availability of mineral nutrients following SS may be attributed to release of the nutrients tied up in the organic soil fraction as well as exchange complexes (example $\mathrm{NH}_{4}-\mathrm{N}, \mathrm{NO}_{3}-\mathrm{N}, \mathrm{P}, \mathrm{Ca}$, and $\mathrm{Mg}$ ). An increase in soil nitrate nitrogen by more than $3000 \mathrm{~kg} \mathrm{ha}^{-1}$ was obtained by growing mustard and incorporating it into soil before SS [3].

All Xcv-inoculated seeds were treated with 'Atella' and the tomato leaf spot disease symptom did not develop on the tomato seedlings because 'Atella' was found to be efficient in suppressing Xcv growth and proliferation on tomato seed [17]. Additionally, Xcv in the soil could not spread to the leaves of the tomato plants because the disease is not systemic and the tomato plants were grown in a glasshouse and there were no rain splashes which might have increased the disease spread.

\section{CONCLUSION}

This study revealed that the effect of soil solarisation and bio-fumigation on Xanthomonas campestris pv. vesicatoria in the soil was non-significant. However, the use of soil solarisation and bio-fumigation increased the yield of tomato in the presence of Xanthomonas campestris pv. vesicatoria in the soil possibly because of the concomitant enhancement of soil physico-chemical properties that are conducive for tomato growth and development. The bacteria present in the soil have less impact if there is no rain splash. The results of the study also revealed that the use of 'Atella' to treat the seed and reducing contact of the tomato leaves with the soil were helpful in reducing the disease caused by Xanthomonas campestris pv. vesicatoria. 


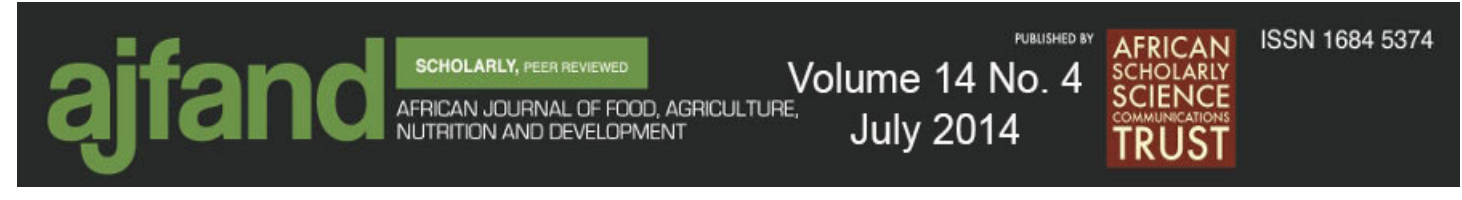

\section{ACKNOWLEDGMENTS}

The authors would like thank Dr. J.B. Jones of Florida University, USA for identifying the bacterial isolates. The financial support provided by SIDA is gratefully acknowledged. We thank Haramaya University for facilitating release of the fund for the research work. 


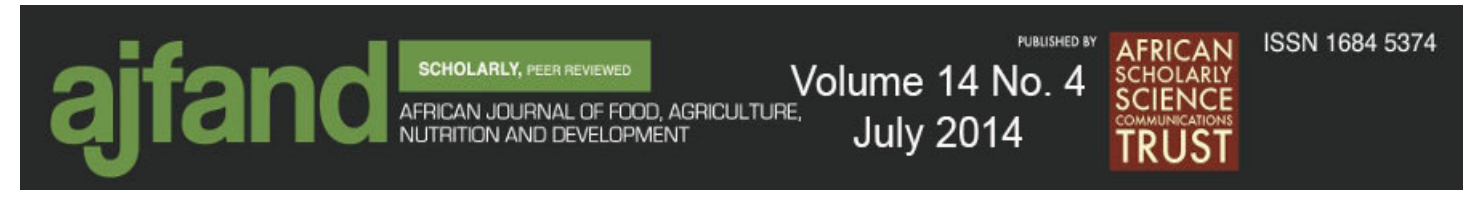

Table 1: Average daily temperature $\left({ }^{\circ} \mathrm{C}\right)$ of Haramaya and Dire Dawa for May and June during the study periods

\begin{tabular}{l|ccccc}
\hline \multirow{2}{*}{ Temperature } & \multicolumn{3}{|c}{ Haramaya } & \multicolumn{3}{c}{ Dire Dawa } \\
\cline { 2 - 6 } & 2011 & 2012 & 2010 & 2011 & 2012 \\
\hline Minimum & 11.5 & 12.6 & 16.5 & 17.4 & 17.3 \\
Maximum & 29.0 & 27.5 & 37.5 & 38.0 & 37.0 \\
Mean & 18.9 & 18.4 & 27.3 & 27.9 & 27.4 \\
Standard Deviation & 5.2 & 4.8 & 6.5 & 6.4 & 6.6 \\
\hline
\end{tabular}

Source: National Meteorological Agency, Ethiopia 2013 


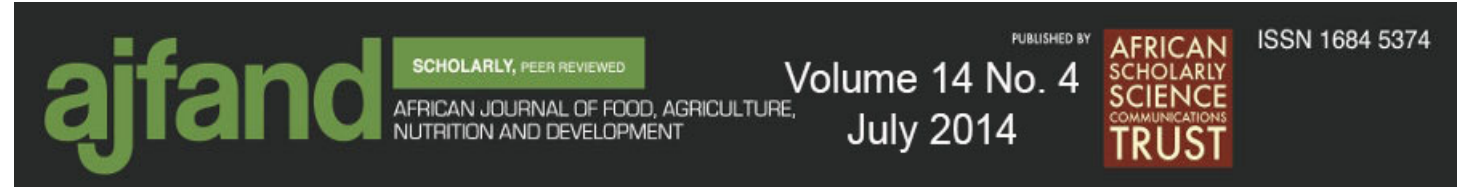

Table 2: Mean total microbial counts ${ }^{1}\left(\log _{10} \mathrm{CFU} \mathrm{g}^{-1}\right)$ as influenced by soil treatments

\begin{tabular}{|c|c|c|c|c|}
\hline Soil treatment & Bacteria & Actinomycete & Fungi & $\mathrm{Xcv}^{2}$ \\
\hline Un- inoculated soil & 10.73ab & $11.05 \mathrm{ab}$ & 9.50a & 0c \\
\hline Mustard mixed un-inoculated soil & 10.68ab & 11.29ab & $10.55 a$ & 0c \\
\hline Inoculated soil & $11.27 \mathrm{a}$ & 11.69a & $10.67 \mathrm{a}$ & $10.68 \mathrm{a}$ \\
\hline Mustard mixed inoculated soil & $11.45 a$ & 11.48ab & $9.94 \mathrm{a}$ & $10.57 \mathrm{a}$ \\
\hline Biofumigated inoculated soil & $11.27 \mathrm{a}$ & $10.12 b c$ & 9.64a & $8.79 b$ \\
\hline Solarised inoculated soil & $9.86 \mathrm{~b}$ & $9.44 c$ & $9.72 \mathrm{a}$ & $8.79 b$ \\
\hline $\begin{array}{l}\text { Both biofumigated and solarised } \\
\text { inoculated soil }\end{array}$ & 11.63a & $10.71 \mathrm{abc}$ & $9.32 \mathrm{a}$ & $8.84 b$ \\
\hline $\begin{array}{l}\text { Non-solarised non- biofumigated } \\
\text { inoculated soil after a month }\end{array}$ & 11.49a & 11.09ab & $9.1 \mathrm{a}$ & $8.62 b$ \\
\hline $\mathrm{CV}$ & 8.58 & 7.32 & 9.30 & 10.73 \\
\hline LSD & 1.01 & 1.26 & 1.44 & 1.16 \\
\hline
\end{tabular}




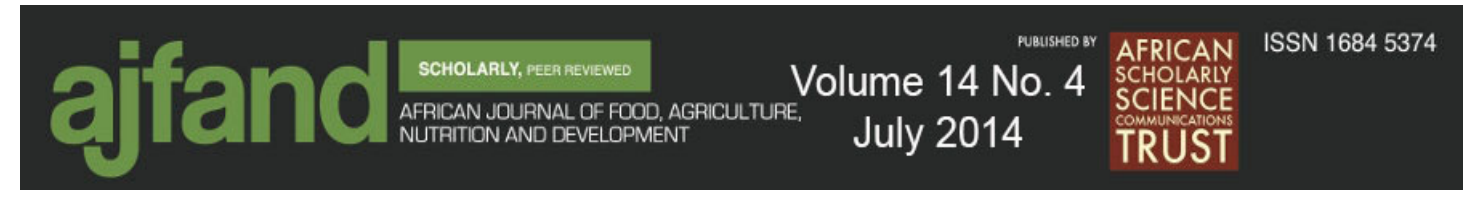

Table 3: Mean yield of tomato as influenced by soil treatments at two locations in eastern Ethiopia, 2012

\begin{tabular}{|c|c|c|}
\hline Soil treatment & Yield per pot (g) & $\begin{array}{l}\text { Yield per } \\
\text { hectare } \\
\text { (tons) }\end{array}$ \\
\hline Biofumigated & 2129.33c & 45.78c \\
\hline Solarised at Haramaya & 1485.33e & $31.94 \mathrm{e}$ \\
\hline Solarised at Dire Dawa & 1667.67d & $35.85 d$ \\
\hline Biofumigated solarised at Haramaya & 2683.33b & $57.69 b$ \\
\hline Biofumigated solarised at Dire Dawa & $4240.67 a$ & 91.18a \\
\hline Non- solarised non- biofumigated inoculated soil & 1429.0f & $30.72 \mathrm{f}$ \\
\hline LSD & 31.21 & 0.67 \\
\hline $\mathrm{CV}$ & 1.19 & 1.2 \\
\hline
\end{tabular}




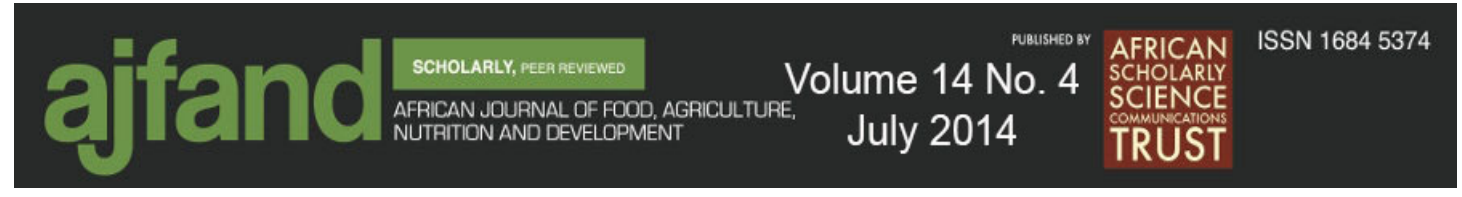

Table 4: Solarised pots average daily temperature $\left({ }^{\circ} \mathrm{C}\right)$ at Haramaya and Dire Dawa, during May-June 2012

\begin{tabular}{|c|c|c|c|c|c|c|}
\hline Area & Time & Depth & Minimum & Maximum & Mean & Std Dev \\
\hline \multirow[t]{8}{*}{ Haramaya } & $6: 00 \mathrm{am}$ & $5 \mathrm{~cm}$ & 14 & 20 & 17.79 & 1.66 \\
\hline & & $15 \mathrm{~cm}$ & 15 & 22 & 19.70 & 1.37 \\
\hline & $10 \mathrm{am}$ & $5 \mathrm{~cm}$ & 10 & 38 & 26.54 & 6.09 \\
\hline & & $15 \mathrm{~cm}$ & 20 & 45 & 27.61 & 5.16 \\
\hline & $2: 00 \mathrm{pm}$ & $5 \mathrm{~cm}$ & 25 & 53 & 41.32 & 8.26 \\
\hline & & $15 \mathrm{~cm}$ & 22 & 55 & 47.74 & 7.5 \\
\hline & 6:00 pm & $5 \mathrm{~cm}$ & 25 & 47 & 36.18 & 6.17 \\
\hline & & $15 \mathrm{~cm}$ & 29 & 53 & 42.63 & 5.51 \\
\hline \multirow[t]{8}{*}{ Dire Dawa } & $6: 00 \mathrm{am}$ & $5 \mathrm{~cm}$ & 20 & 30 & 24.34 & 2.59 \\
\hline & & $15 \mathrm{~cm}$ & 23 & 30 & 26.03 & 1.59 \\
\hline & $10 \mathrm{am}$ & $5 \mathrm{~cm}$ & 30 & 55 & 43.69 & 5.98 \\
\hline & & $15 \mathrm{~cm}$ & 33 & 46 & 38.72 & 3.07 \\
\hline & 2:00 pm & $5 \mathrm{~cm}$ & 46 & 60 & 53.00 & 3.82 \\
\hline & & $15 \mathrm{~cm}$ & 43 & 58 & 49.96 & 3.39 \\
\hline & $6: 00 \mathrm{pm}$ & $5 \mathrm{~cm}$ & 30 & 47 & 39.34 & 4.93 \\
\hline & & $15 \mathrm{~cm}$ & 35 & 49 & 41.97 & 3.54 \\
\hline
\end{tabular}




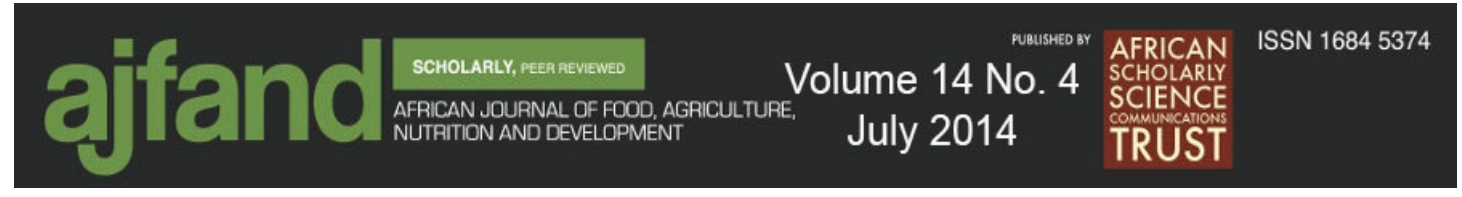

\section{REFERENCES}

1. Antoniou P, Tjamos EC and CG Panagopoulos Use of soil solarisation for controlling bacterial canker of tomato in plastic houses in Greece. Plant Pathol.1995; 44: 438-447.

2. Stapleton JJ and JE DeVay Effect of soil solarisation on population of selected soil-borne micro-organisms and growth of deciduous fruit tree seedlings. Phytopathol. 1982; 72: 323-326.

3. Pokharel $\mathbf{R}$ Soil Solarisation, an alternative to soil fumigants [Internet]. Colorado State University, U.S. Department of Agriculture, and Colorado counties cooperating. CSU Extension programs, Available from http://www.ext.colostate.edu/pubs/crops/00505.html Retrieved June 2013.

4. Stevens C, Khan VA, Rodriguez-Kabana R, Proper LD, Backman PA, Collins DJ, Brown JE, Wilson MA and ECK Iqebe Integration of soil solarisation with chemical, biological and cultural control for the management of soil-borne diseases of vegetables. Plant and Soil 2003; 253: 493-506.

5. Fahey JW, Zalcmann AT and $\mathbf{P}$ Talalay The chemical diversity and distribution of glucosinolates and isothiocyanates among plants. Phytochem. 2001; 56: 5-51.

6. Mithen RF Glucosinolates and their degradation products. Adv. in Botanical Res. 2001; 35: 213-262.

7. Rosa E, Heaney RK, Fenwick GR and CAM Portas GSLs in crop plants. Horti. Reviews 1997; 19: 99-215.

8. Rask L, Andreasson E, Ekbom B, Eriksson S, Pontoppidan B and $\mathbf{J}$ Meijer Myrosinase: Gene family evolution and herbivore defence in Brassicaceae. Plant Mol. Biol. 2000; 42: 93-113.

9. Dufour V, Alazzam B, Ermel G, Thepaut M, Rossero A, Tresse O and C Baysse Antimicrobial activities of isothiocyanates against Campylobacter jejuni isolates. Front Cell Infect Microbiol. 2012; 2: 53.

10. Walker JC, Morell S and $\mathbf{H}$ Foster Toxicity of mustard oils and related sulphur compounds to certain fungi. American J. Botany 1937; 24: 536-541. 


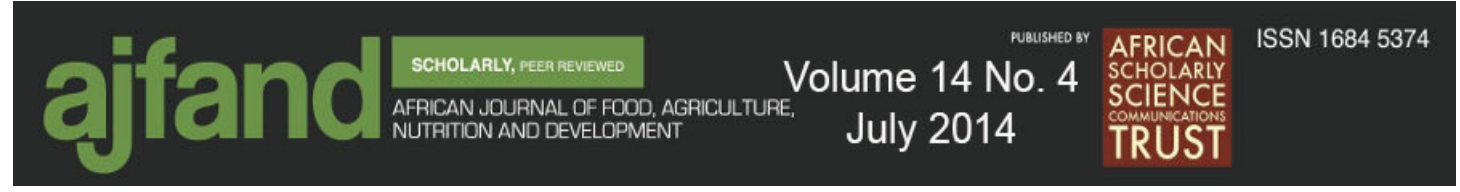

11. McGuire AM Mustard green manure crops replace fumigant and improve infiltration in potato cropping system. Agroindustria 2004; 3:331-333.

12. Kirkegaard $\mathbf{J}$ Bio-fumigation for plant disease control, form the fundamentals to the farming system. In: Dale Walters, (Eds.). Disease Control in Crops Biological and Environmentally Friendly Approaches. Blackwell Publishing Ltd. 2009: 172-192.

13. Márquez-Lema AF, Martínez JM, Pérez-Vich B and L Velasco Inheritance of very high glucosinolate content in Ethiopian mustard seeds. Plant Breeding 2009; 128: 278-281.

14. Shimelis $\mathbf{H}$ Response of cabbage cultivars to black rot infection. Afri.Crop Sci. J. 2005; 13:185-192.

15. Abbasi PA and G Lazarovits Effect of acidic electrolyzed water on the viability of bacterial and fungal plant pathogens and on bacterial spot disease of tomato. Can. J. Microbiol. 2006; 52: 915-923.

16. Stall RE, Jeffrey BJ and VM Gerald Durability of resistance in tomato and pepper to Xanthomonads causing bacterial spot. Annu. Rev. Phytopathol. 2009; 47:265-84.

17. Kritzman G A method for detection of seed borne bacterial diseases in tomato seeds. Phytoparasitica 1991; 19:133-141.

18. Kebede $M$, Ayalew A and $M$ Yesuf Efficacy of seed treatment by plant extracts, traditional materials, and antibacterial chemicals against Xanthomonas campestris pv. vesicatoria. Afri. J. Microbiol. Res. 2013; 7: 2395-2400.

19. Matthiessen JN, Warton B and MA Shackleton The importance of plant maceration and water addition in achieving high Brassica-derived isothiocyanate levels in soil. Agroindustria 2004; 3: 277-280.

20. Widodo BT Suppression of Fusarium root rot and Southern blight on peanut by soil solarisation. J. ISSAAS 2009; 15: 118-125.

21. Schaad NW, Jones JB and GH Lacy Gram negative bacteria, Xanthomonas. In: NW Schaad, JB Jones and W Chun (Eds). Laboratory Guide for identification of plant pathogenic bacteria. American Phytopathological Society. USA 2001. 


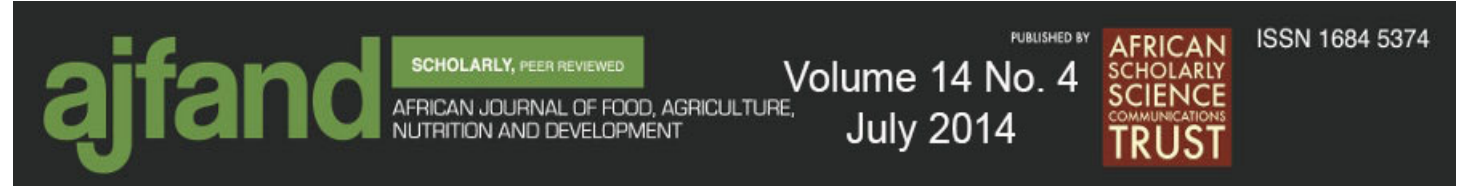

22. Brock TD Thermophilic Microorganisms and Life at High Temperatures. Springer-Verlag, New York. 1978:465.

23. Opara EU and FT Obani Performance of some plant extracts and pesticides in the control of bacterial spot disease of Solanum. Agri. J. 2009; 4: 250-253.

24. Ali MZ, Waseem I, Adel K and M Muftah Soil solarisation. In: ED James, JS James and LE Clyde (Eds). Proceedings of the First International Conference on Soil Solarisation. FAO plant production and protection paper 109 food and agriculture organization of the United Nations. Amman, Jordan 1991.

25. Katan J Solar heating (solarisation) of soil for control of soil borne pests. Ann. Review of Phytopathol. 1981; 63: 211-236.

26. Katan J Soil solarisation. In: I Chet (Ed). Innovative Approaches to Plant Disease Control. John Wiley \& Sons, New York. 1987:77-105.

27. Wang AS, Ping HU, Emily BH, Katie LR, Anil S, Tony LP, Frank M H and JG Terry Impact of Indian mustard (Brassica juncea) and flax (Linum usitatissimum ) seed meal applications on soil carbon, nitrogen, and microbial dynamics. App. Environmental Soil Sci. 2012; Article ID 351609, 14 pages.

28. Reeves DW The role of soil organic matter in maintaining soil quality in continuous cropping systems Soil \& Tillage. Research 1997; 43: 131-167.

28. A, Ahmed S, Finnisa C, Parshotham KS and G Alemayehu Effect of Brassica carinata (L.) bio-fumigants (seed meal) on chickpea wilt (Fusarium oxysporum f.sp.ciceris), growth, yield and yield components in Ethiopia. Arc. Phytopathol. and Plant Prot. 2011; 44: 1785-1795.

29. Harvey SG and ES Carl Brassica bio-fumigation increases marketable tomato yield. Knoxville Experiment Station. The University of Tennessee Institute of Agriculture, Konxville, TN 37996. 2001.

30. Dubey RC, Harish K and RR Pandey Combined effect of soil solarisation and neem amendment on survival of Macrophomina phaseolina sclerotia and growth of soybean. Nature and Sci. 2009; 7: 52-57. 